\title{
Desenvolvimento e avaliação de um ensaio imunoenzimático para o diagnóstico sorológico da infecção pelo herpesvírus bovino 1
}

\section{Development and evaluation of an enzyme-linked immunosorbent assay for the serological diagnosis of the bovine herpesvirus 1 infection}

\author{
Melissa C. Ferreira ${ }^{1}$; Kerlei C. Médici²; Alice F. Alfieri²; Amauri A. Alfieri ${ }^{2 *}$
}

Resumo

\begin{abstract}
Um ensaio imunoenzimático (ELISA) indireto utilizando antígeno não purificado foi desenvolvido para o diagnóstico sorológico da infecção pelo herpesvírus bovino 1 (BoHV-1). Nos experimentos de padronização várias substâncias bloqueadoras de reações inespecíficas foram avaliadas em diferentes concentrações e associações. Os melhores resultados foram obtidos utilizando-se leite em pó desnatado (5\%) como solução de bloqueio e o tampão de diluição dos soros/conjugado acrescido de células MDBK (10\%), soro de eqüino (10\%) e leite em pó desnatado (1\%). O sistema foi avaliado frente a uma coleção de soros bovinos positivos $(n=60)$ e negativos $(n=62)$ para o BoHV-1 por meio da técnica de soro-neutralização (SN). O ELISA indireto padronizado nesse estudo, quando comparado com a SN, apresentou $98,3 \%$ de sensibilidade e $96,8 \%$ de especificidade (kappa: 0,93), valores que possibilitam a sua implantação na rotina laboratorial para o diagnóstico sorológico da infecção pelo BoHV-1. O desenvolvimento de um sistema de ELISA indireto utilizando antígeno não purificado facilita a elaboração da técnica, reduz o custo de produção e possibilita a sua aplicação em inquéritos soroepidemiológicos da infecção pelo BoHV-1 em rebanhos bovinos.
\end{abstract}

Palavras-chaves: Bovino, herpesvírus bovino 1, sorologia, ELISA indireto

\begin{abstract}
An indirect enzyme-linked immunosorbent assay (ELISA) using non-purified antigen was developed for serological diagnosis of the bovine herpesvirus 1 (BoHV-1) infection. Some blocking substances to prevent nonspecific reactions were evaluated in different concentrations and combinations. The best results were obtained using 5\% skim milk powder as blocking solution and the serum/conjugated buffer added with $10 \%$ MDBK cells, $10 \%$ equine serum, $1 \%$ skim milk powder. The system was evaluated with a collection of positives $(n=60)$ and negatives $(n=62)$ bovine serum previously analyzed by seroneutralization (SN) technique for the BoHV-1 antibodies. The indirect ELISA standardized showed $98.3 \%$ of sensitivity and $95.2 \%$ of specificity (kappa: 0.93 ) when compared with the SN technique. These results would allow its implantation in the laboratorial routine for the serological diagnosis of the BoHV1 infection. The use of non-purified antigen in ELISA facilitate the elaboration, reduces the production cost and makes possible the application of these technique in seroepidemiological study of the BoHV-1 infection in cattle herds.
\end{abstract}

Key words: Cattle, bovine herpesvirus 1, serology, Indirect ELISA

1 Aluna do Programa de Pós-graduação em Ciência Animal (Área de Concentração: Sanidade Animal; Nível: Mestrado), Centro de Ciências Agrárias (CCA), Universidade Estadual de Londrina (UEL).

2 Laboratório de Virologia Animal, Departamento de Medicina Veterinária Preventiva, CCA, UEL, Campus Universitário, caixa postal 6001, CEP. 86051-990, Londrina, Paraná, Brasil.

* Autor para correspondência E-mail: alfieri@uel.br. 


\section{Introdução}

O herpesvírus bovino 1 (bovine herpesvirus 1 BoHV-1-), membro da família Herpesviridae, é considerado um dos principais patógenos de bovinos, responsável por grandes prejuízos econômicos à exploração pecuária (KIRKBRIDE, 1985; ROIZMAN et al., 1992). A infecção pelo BoHV-1, na dependência da idade do animal, da via de infecção e da estirpe viral, pode causar sinais clínicos distintos, destacando-se os problemas do trato respiratório superior (rinotraqueíte infecciosa bovina-IBR-), do trato genital (vulvovaginite e balanopostite pustular infecciosa -IPV/IPB-), conjuntivite, e distúrbios reprodutivos como infertilidade, mortalidades embrionária e fetal, natimortalidade e mortalidade neonatal (GIBBS; RWEYEMANN, 1977; KAHRS, 1977; FENNER, 1987; WYLER; ENGELS; SCHWYZR, 1989; ALFIERI; ALFIERI; MÉDICI, 1998; STRAUB, 1991; OKANO et al., 2003; TAKIUCHI et al., 2005).

O BoHV-1 encontra-se amplamente disseminado em rebanhos bovinos de todo o mundo, excetuandose apenas alguns países da Europa ocidental que implantaram programas de erradicação dessa virose (ACKERMANN et al., 1990). Estudos soroepidemiológicos, realizados em várias regiões geográficas, têm demonstrado a grande disseminação do BoHV-1 nos rebanhos bovinos brasileiros, tanto com aptidão para a produção de carne quanto de leite, com freqüência de anticorpos (Ac) variando entre 42,1 a 91,2\%, (MUELLER et al., 1981; RAVAZZOLO; PIZZOL; MOOJEN, 1989; VIDOR et al., 1995; RICHTZENHAIN et al., 1999; MÉDICI; ALFIERI; ALFIERI, 2000; TAKIUCHI; ALFIERI; ALFIERI, 2001).

O diagnóstico da infecção pelo BoHV-1 pode ser realizado por meio de métodos que identificam o agente etiológico, a partir de material biológico obtido de animais com sinais clínicos da infecção ou de fetos abortados, como o isolamento viral em cultivo celular, a imunofluorescência e a imunoperoxidase diretas e a reação em cadeia da polimerase (WYLER;
ENGELS; SCHWYZR, 1989; TAKIUCHI et al., 2003; 2005).

A detecção de anticorpos para o BoHV-1 em soros bovinos, apesar de não representar uma ferramenta de diagnóstico etiológico em animais com sinais clínicos, é uma estratégia fundamental para demonstrar a presença do vírus no rebanho, e também para quantificar o número de animais infectados. A sorologia para o BoHV-1 também é importante para o monitoramento da infecção em rebanhos bovinos tanto para a definição de estratégias de controle e profilaxia, como a vacinação, quanto para a erradicação da infecção. As técnicas mais utilizadas com essa finalidade são a soroneutralização (SN) e o ensaio imunoenzimático (ELISA) indireto. A SN é considerada a técnica padrão porém, é laboriosa, demorada e requer condições laboratoriais que possibilitem a manutenção de linhagens celulares (MÉDICI; ALFIERI; ALFIERI, 2000a).

Devido à facilidade na elaboração da técnica e a possibilidade da análise simultânea de grande número de amostras, a técnica de ELISA é a mais rotineiramente utilizada para a detecção de anticorpos para o BoHV-1 em soros bovinos (WYLER; ENGELS; SCHWYZR, 1989). No Brasil, para a realização de sorologia para o BoHV-1 por ELISA indireto são disponíveis apenas kits comerciais importados, o que aumenta consideravelmente o custo do diagnóstico (MÉDICI; ALFIERI; ALFIERI, 2000a; CORTEZ et al., 2001).

Este trabalho teve como objetivo desenvolver e avaliar um sistema de ELISA indireto para a detecção de anticorpos para o BoHV-1 em soros bovinos, utilizando a técnica de SN como padrão de referência.

\section{Material e Métodos}

Células e Virus

A estirpe Los Angeles (LA) do BoHV-1 foi amplificada em células MDBK (Madin Darby bovine kidney) mantidas em meio Dulbecco 
modificado (DMEM, Gibco BRL, EUA) suplementado com $7 \%$ de soro fetal bovino (SFB Gibco BRL, EUA) livre de micoplasmas e vírus, 55 $\mathrm{mg} / \mathrm{mL}$ de gentamicina (Sigma ${ }^{\circledR}$ Co., EUA) e $2,5 \mathrm{mg} /$ $\mathrm{mL}$ de anfotericina B (Sigma ${ }^{\circledR}$ Co., EUA). Para a produção do BoHV-1 em cultivo celular a concentração do SFB presente no meio de cultura celular DMEM foi reduzida para 1\%. O título viral presente na suspensão foi calculado em dose infecciosa $50 \%$ para cultura de tecidos $(50 \%$ tissue culture infective doses $-\mathrm{TCID}_{50}$ ). O BoHV-1 foi utilizado tanto para a realização da técnica de SN quanto para a produção de antígeno para a técnica de ELISA indireto. A linhagem de células MDBK utilizada para a produção do antígeno BoHV-1 foi monitorada pela técnica da RT-PCR e encontrava-se livre do vírus da diarréia viral bovina (dados não mostrados), contaminante freqüente de linhagens celulares mantidas em meio de cultura suplementado com SFB.

\section{Amostras de soros sangüineos}

Como soros sangüíneos de referência, negativo e positivo, foram utilizados dois pools de soros, constituídos por até 10 amostras cada pool. A ausência ou a presença de anticorpos para o BoHV1 , tanto nas amostras individuais quanto nos pools, foi avaliada pela SN e também por um sistema de ELISA indireto comercial (Bovine Rhinotracheitis virus antibody test kit, HerdChek ${ }^{\circledR}$, IDEXX Laboratories, Inc. EUA). Para a validação do ELISA indireto, desenvolvido nesse trabalho, foram selecionadas 122 amostras de soro, previamente avaliadas em triplicata pela SN, sendo 60 amostras positivas e 62 amostras negativas, colhidas de animais adultos provenientes de rebanhos bovinos, com aptidão para a produção de carne ou de leite, da Região Norte do Estado do Paraná.

\section{Técnica de Soro-neutralização}

A titulação dos anticorpos para o BoHV-1 foi realizada de acordo com a microtécnica de SN descrita por Bitsch (1978). Após prévia inativação a $56^{\circ} \mathrm{C} / 30$ min, diluições seriadas em base 2 (1:2 a 1:64) dos soros, realizadas em meio DMEM, foram distribuídas em triplicata em microplacas de 96 cavidades contendo $100 \mathrm{TCID}_{50}$ por cavidade da estirpe LA do BoHV-1. Após incubação por $1 \mathrm{~h}$ a $37^{\circ} \mathrm{C}$ uma suspensão contendo $4 \times 10^{4}$ células MDBK/cavidade, em meio DMEM, foi adicionada e as placas incubadas a $37^{\circ} \mathrm{C}$ em atmosfera de $5 \%$ de $\mathrm{CO}_{2}$ por três dias. Foram considerados positivos os soros que nas diluições $>1: 4$ inibiram 100\% do efeito citopático (ECP) do BoHV-1.

\section{Produção de antígeno-BoHV-1 para ELISA}

Monocamadas de células MDBK inoculadas com a estirpe LA do BoHV-1 (100 TCID $\left._{50}\right)$ foram incubadas a $37^{\circ} \mathrm{C}$ por $72 \mathrm{~h}$. Com aproximadamente $80 \%$ de ECP as células, ainda aderidas, foram removidas e a mistura células/meio de cultura celular foi centrifugada a $5.000 \mathrm{x}$ g por $30 \mathrm{~min}$ a $4^{\circ} \mathrm{C}$. As duas frações resultantes, o sobrenadante (fração A) e o sedimento celular (fração B), foram processadas individualmente.

A fração A foi concentrada por precipitação com polietilenoglicol (PEG) 6000 (Sigma ${ }^{\circledR}$ Co., EUA) de acordo com o método descrito por Gould et al. (1985). Sob agitação suave e constante, em banho de gelo, lentamente foram acrescentados $\mathrm{NaCl}$ e PEG até a concentração final de 2,3\% e 7\%, respectivamente. Após a completa dissolução do PEG a mistura foi mantida sob agitação a $4^{\circ} \mathrm{C}$ por um período mínimo de 3 h ou máximo de uma noite e, então, centrifugada a $15.000 \mathrm{x} \mathrm{g} \mathrm{a} 4^{\circ} \mathrm{C}$ por $20 \mathrm{~min}$. O sedimento, resultante da centrifugação, foi reconstituído em 1 a $5 \%$ do volume original com TES (10 mM Tris- $\mathrm{HCl} ; 2 \mathrm{mM}$ EDTA; $150 \mathrm{mM} \mathrm{NaCl}$ ), sonicado a $60 \mathrm{~mA}$ por três períodos de $15 \mathrm{~s}$ em banho de gelo, acrescido Tween 20 (Sigma ${ }^{\circledR}$ Co., EUA) até atingir a concentração final de $2 \%$, homogeneizado por $2 \mathrm{~h}$ à temperatura ambiente, e clarificado por centrifugação a 5.000 x g por $15 \min$ a $4^{\circ} \mathrm{C}$. 
A fração B (sedimento celular), originada da primeira centrifugação, foi reconstituída em $10 \mathrm{~mL}$ de tampão TES, submetida a três ciclos rápidos de congelamento / descongelamento e centrifugada a $15.000 \mathrm{x} \mathrm{g}$ por $20 \mathrm{~min}$ a $4^{\circ} \mathrm{C}$. O sobrenadante foi concentrado com $\mathrm{NaCl}$ e $\mathrm{PEG}$ e centrifugado como descrito anteriormente. O sedimento foi ressuspenso em PBST 2\% (9,3 $\mathrm{mM} \mathrm{Na}_{2} \mathrm{HPO}_{4} ; 1,5 \mathrm{mM}$ $\mathrm{NaH}_{2} \mathrm{PO}_{4} ; 150 \mathrm{mM} \mathrm{NaCl}, 2 \%$ Tween 20), homogeneizado por $2 \mathrm{~h}$ à temperatura ambiente, com posterior sonicação (3 ciclos de $15 \mathrm{~s}$ a $60 \mathrm{~mA}$ ) e centrifugação, como descrito anteriormente.

Os produtos das frações A e B foram mesclados, homogeneizados e estocados $\mathrm{a}-70^{\circ} \mathrm{C}$ em alíquotas de $1 \mathrm{~mL}$, que foram utilizadas como antígeno-BoHV1 na técnica de ELISA.

\section{Determinação da concentração de proteína}

A concentração de proteína obtida no antígenoBoHV-1 foi determinada pelo método de Bradford (1976), sendo o antígeno ressuspenso em tampão TES até atingir o valor de 63,96 mg de proteína/mL.

\section{Otimização do ELISA indireto}

As melhores diluições do antígeno, do soro e do conjugado a serem utilizadas no ELISA indireto foram determinadas por meio de um sistema de titulação cruzada empregando soros negativos e positivos para anticorpos anti-BoHV-1. Foram selecionadas, pela análise da densidade óptica (DO), as diluições que proporcionaram maior evidência da distinção entre os soros positivos e negativos. Para a elaboração das soluções de bloqueio de reações inespecíficas e diluente do soro foram avaliados vários constituintes (PBST, leite em pó desnatado, soro fetal bovino, soro de bovino adulto negativo para anticorpos anti-BoHV1, células MDBK, soro normal de coelho, soro de eqüino adulto, soro albumina bovina e meio de cultivo celular com ou sem soro fetal bovino) em diferentes concentrações e associações, sendo selecionados aqueles que proporcionaram menor ruído quando testados frente ao soro negativo.

\section{ELISA indireto}

Microplacas de poliestireno com 96 cavidades (Nunc-Immuno Plate, MaxiSorp ${ }^{\mathrm{TM}}$, Dinamarca) foram adsorvidas com $70 \mu \mathrm{g} /$ cavidade do antígenoBoHV-1 em $120 \mathrm{~mL}$ de tampão carbonato/ bicarbonato $\mathrm{pH}$ 9,6 (15 $\mathrm{mM} \mathrm{Na}_{2} \mathrm{CO}_{3} ; 35 \mathrm{mM}$ $\mathrm{NaHCO}_{3}$ ) e incubadas por $18 \mathrm{~h}$ a $4^{\circ} \mathrm{C}$ em câmara úmida. Após esse período as placas foram imediatamente utilizadas ou armazenadas a $-20^{\circ} \mathrm{C}$ para uso posterior. Anteriormente a utilização as placas foram lavadas seis vezes com PBST 0,05\% $\mathrm{pH} \mathrm{7,6}\left(9 \mathrm{mM} \mathrm{Na}_{2} \mathrm{HPO}_{4} ; 1 \mathrm{mM} \mathrm{NaH} \mathrm{PO}_{4} ; 150 \mathrm{mM}\right.$ $\mathrm{NaCl} ; 0,05 \%$ Tween 20). Em seguida, foram adicionados $150 \mu \mathrm{L}$ de solução bloqueadora constituída por $5 \%(\mathrm{p} / \mathrm{v})$ de leite em pó desnatado (Molico ${ }^{\circledR}$, Nestlé, BR) diluído em PBST 0,05\%. Após 60 min de incubação a $37^{\circ} \mathrm{C}$ em câmara úmida as placas foram lavadas três vezes em solução PBST $0,05 \%$. Na seqüência, foram adicionados a cada quatro cavidades (4 repetições), $100 \mu \mathrm{L} /$ cavidade de cada soro a ser testado, na diluição 1:25 em PBST 0,05\% acrescido de células MDBK (10\%), de soro estéril de eqüino adulto (10\%) e de leite em pó desnatado (1\%). Após incubação por $90 \mathrm{~min}$ a $37^{\circ} \mathrm{C}$, as placas foram novamente lavadas por três vezes em PBST 0,05\%. Foram adicionados, em cada cavidade da placa, $100 \mu \mathrm{L}$ da diluição 1:20.000 de imunoglobulina de coelho anti-IgG bovina conjugada com peroxidase (Sigma ${ }^{\circledR}$ Co., EUA) em PBST 0,05\% acrescido de $1 \%$ de soro albumina bovina ( $\operatorname{InLab}^{\circledR}$, BR), seguindo-se a incubação por $30 \min$ a $37^{\circ} \mathrm{C}$ em câmara úmida. Após esse período as placas foram novamente lavadas por cinco vezes em PBST 0,05\% e adicionados $100 \mu \mathrm{L} /$ cavidade de tampão ácido cítrico/fosfato $\mathrm{pH} \mathrm{5,0}\left(100 \mathrm{mM} \mathrm{H}_{3} \mathrm{C}_{6} \mathrm{H}_{5} \mathrm{O}_{7} ; 200 \mathrm{mM}\right.$ $\mathrm{Na}_{2} \mathrm{HPO}_{4}$ ) acrescido de $0,005 \%$ orthophenylene diamine (Sigma ${ }^{\circledR} \mathrm{Co}$, EUA) e $0,03 \%$ de $\mathrm{H}_{2} \mathrm{O}_{2}$ como substrato. As placas foram então incubadas à temperatura ambiente por 15 min em câmara escura 
e, após esse período, as reações foram interrompidas pela adição de $25 \mu \mathrm{L} /$ cavidade de uma solução contendo $3 \mathrm{~N} \mathrm{HCl}$. Em cada placa foram incluídos, também em quadruplicata, controles positivo e negativo (soros sangüíneos), e controles do conjugado e do substrato. A DO, em absorbância, de cada reação foi mensurada em espectrofotômetro para microplacas $\left(\right.$ Emax $^{\circledR}$, IDEXX Laboratories, Inc., EUA) em filtro de $490 \mathrm{~nm}$.

\section{Determinação do valor de $R$ (Relação)}

Para minimizar as variações entre os resultados (DO) obtidos em cada microplaca, a DO de cada soro teste foi expressa como valor de R (Relação) que é calculado com base na DO dos controles negativo e positivo. O cálculo foi realizado de acordo Biondi et al (1996) por meio da seguinte fórmula:

$\mathrm{R}=$ (média das DOs de cada soro teste) - (média da DO do pool negativo) (média da DO do pool positivo) - (média da DO do pool negativo)

\section{Ponto de corte}

O ponto de corte foi calculado a partir do maior valor de $\mathrm{R}$ encontrado nos soros negativos $(n=10)$ analisados separadamente, acrescido de três desvios padrão.

\section{Validação do teste}

As determinações de sensibilidade e de especificidade, dos valores preditivo positivo e negativo e da concordância do ELISA indireto foram realizadas de acordo com a metodologia descrita por Coggon, Rose e Barker (1983). Para a análise estatística foi também aplicado o modelo probabilístico para comparação de testes diagnósticos (GART; BUCK, 1966), e o índice de concordância Kappa que foi avaliado por meio do método proposto por Cohen (1960) utilizando a tabela de interpretação de Landis e Koch (1977).

\section{Resultados}

As médias das DOs do pool de soros negativos e positivos foram, respectivamente, 0.093 e 0.524 .
Os soros negativos, individualmente, apresentaram como menor e maior DO, respectivamente, 0.080 $(\mathrm{R}=-0.030)$ e $0.176(\mathrm{R}=0.193)$. $\mathrm{O}$ desvio padrão dos valores de $\mathrm{R}$ dos soros negativos foi de 0.072 . Os soros $(n=122)$ utilizados para a validação do sistema que apresentaram valor de $\mathrm{R}>0.409$ foram considerados positivos. Com a utilização desse parâmetro, $59(95,2 \%)$ dos 62 soros negativos e $59(98,3 \%)$ dos 60 soros positivos, previamente avaliados pela $\mathrm{SN}$, tiveram os resultados confirmados no ELISA indireto.

A tabela 1 apresenta as comparações dos resultados positivos e negativos obtidos pelas técnicas de SN e ELISA indireto nos 122 soros bovinos incluídos nesse estudo, utilizando como ponto de corte três desvios padrão, bem como as análises de validação do ELISA indireto.

Tabela 1. Comparação dos resultados obtidos nas técnicas de soro-neutralização e ELISA indireto para a detecção de anticorpos para o herpesvírus bovino $1 \mathrm{em}$ soros bovinos e análises de validação do teste ${ }^{a}$.

\begin{tabular}{cccc}
\hline \multirow{2}{*}{ ELISA } & \multicolumn{2}{c}{ SORO-NEUTRALIZAÇAO } & \multirow{2}{*}{ TOTAL } \\
\cline { 2 - 3 } & Positivo & Negativo & \\
\hline Positivo & $59(\mathrm{a})$ & $3(\mathrm{~b})$ & $62(\mathrm{a}+\mathrm{b})$ \\
Negativo & $1(\mathrm{c})$ & $59(\mathrm{~d})$ & $60(\mathrm{c}+\mathrm{d})$ \\
\hline TOTAL & $60(\mathrm{a}+\mathrm{c})$ & $62(\mathrm{~b}+\mathrm{d})$ & $122(\mathrm{a}+\mathrm{b}+\mathrm{c}+\mathrm{d})$ \\
\hline
\end{tabular}

antervalo de confiança (IC): 95\%

Sensibilidade relativa: $(a) /(a+c) \times 100=59 / 60 \times 100=$ 98,3\% (IC=93,4 a 99,9)

Especificidade relativa: $(\mathrm{d}) /(\mathrm{b}+\mathrm{d}) \times 100=59 / 62 \mathrm{x}$ $100=95,2 \%$ (IC $=94,4$ a 97,6$)$

Valor preditivo positivo: $(\mathrm{a}) /(\mathrm{a}+\mathrm{b}) \times 100=59 / 62 \mathrm{x}$ $100=95,2 \%$

Valor preditivo negativo: $(\mathrm{d}) /(\mathrm{c}+\mathrm{d}) \mathrm{x} 100=59 / 60 \mathrm{x}$ $100=98,3 \%$

Concordância: $(\mathrm{a}+\mathrm{d}) /(\mathrm{a}+\mathrm{b}+\mathrm{c}+\mathrm{d})$ x $100=118 / 122$ x

$100=96,7 \%(\mathrm{IC}=95,5$ a 97,1$)$

Kappa $=\mathrm{Po}^{3}-\mathrm{Pe}^{4} / 100-\mathrm{Pe}=0,93$

3 Precisão observada

4 Precisão esperada 
A Figura 1 apresenta os valores de R encontrados no ELISA indireto, de todos os 122 soros bovinos utilizados para validação dessa técnica, distribuídos de acordo com o resultado (positivo ou negativo) encontrado na técnica de SN.
A Figura 2 apresenta a correlação entre as DOs obtidas no ELISA indireto e os títulos de anticorpos neutralizantes detectados na SN.

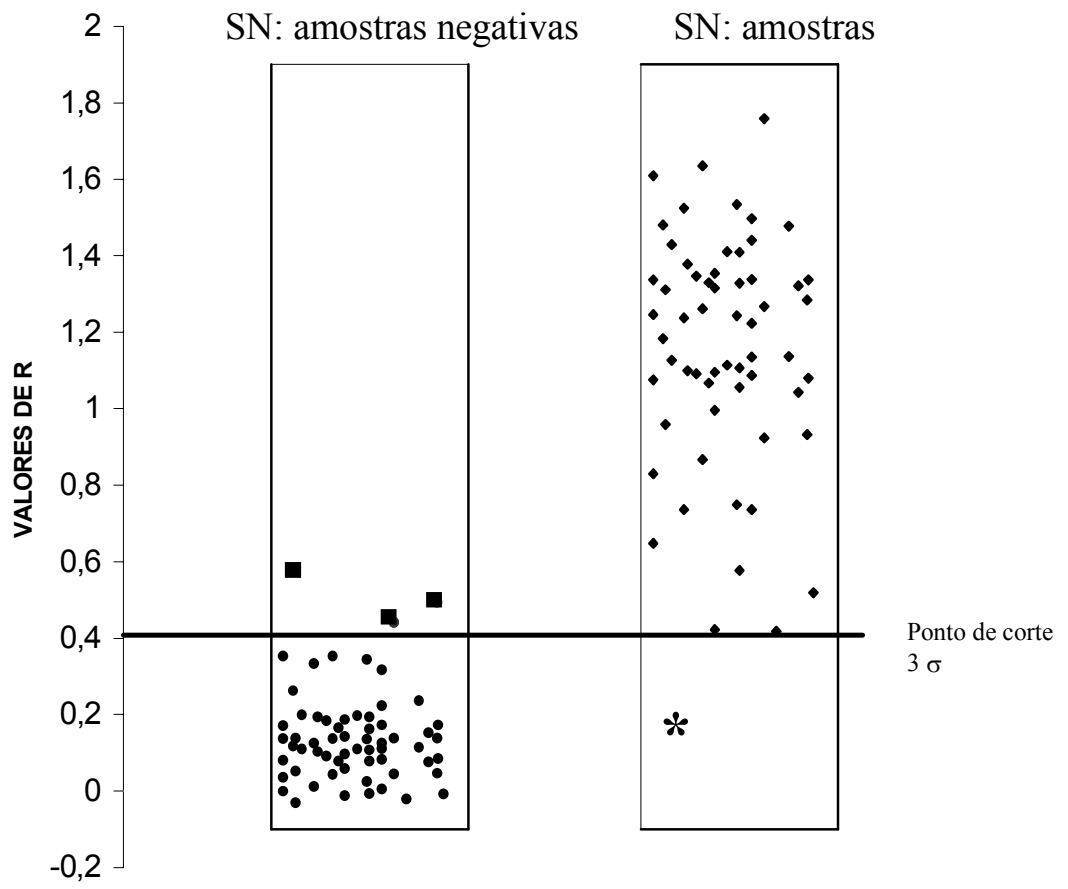

- Falso-positivo no ELISA * Falso-negativo no ELISA

Figura 1. Distribuição dos valores de Relação $(\mathrm{R})$ encontrados no ELISA indireto para detecção de anticorpos para o herpesvírus bovino 1 em soros bovinos negativos $(n=62)$ e positivos $(n=60)$ pela técnica de soro-neutralização.

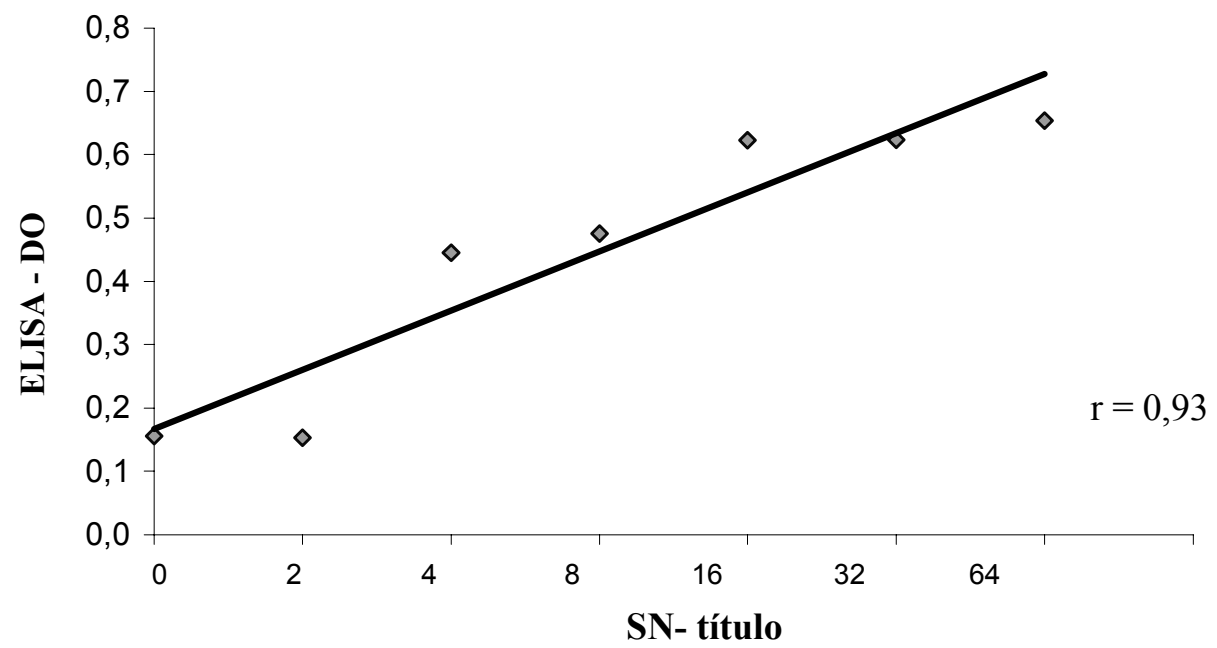

Figura 2. Correlação entre o valor da densidade óptica (DO) em ELISA indireto e o título na soro-neutralização na detecção de anticorpos para o herpesvírus bovino $1 \mathrm{em}$ soros sangüíneos bovinos $(n=122)$ utilizados na validação da técnica de ELISA indireto. Coeficiente de correlação " $r$ " $(r=0,93)$. 


\section{Discussão}

Diferentes sistemas de ELISA para o diagnóstico sorológico da infecção pelo BoHV-1 em bovinos são descritos na literatura. A grande maioria dos sistemas utiliza em fase sólida o BoHV-1 purificado (PAREDES et al., 1999). Por ser um vírus envelopado, os processos de purificação do BoHV1 são laboriosos, envolvem ultracentrifugação e, na dependência do método utilizado, pode ocasionar perda significativa no rendimento, aumentando o custo de produção. O emprego de antígeno bruto, não purificado, com freqüência, ocasiona grande número de reações inespecíficas inviabilizando o diagnóstico. O presente trabalho descreve o desenvolvimento e a avaliação de um sistema de ELISA indireto, que utiliza antígeno não purificado, de fácil padronização e baixo custo de produção.

$\mathrm{O}$ antígeno utilizado foi produzido a partir de preparações simples e rápidas, empregando-se apenas a concentração por meio de métodos químicos, que são facilmente realizados em laboratórios convencionais de virologia que disponham de cultivo celular. Nos trabalhos iniciais de padronização, a principal dificuldade encontrada foi com relação às reações inespecíficas, observadas em amostras de soros bovinos utilizados como controles negativos para o BoHV-1 e que apresentavam resultados falsopositivos. Para solucionar esse problema várias substâncias, classicamente utilizadas em sistema de ELISA como bloqueadoras de reações inespecíficas, foram avaliadas em diferentes concentrações e combinações, tanto para a elaboração do tampão de bloqueio, quanto dos diluentes do soro e do conjugado. Os melhores resultados foram obtidos utilizando-se leite em pó desnatado como solução de bloqueio e o tampão de diluição dos soros/ conjugado constituído por PBST 0,05\% acrescido de células MDBK (10\%), soro de eqüino adulto $(10 \%)$ e leite em pó desnatado (1\%).

A inclusão de células MDBK no tampão de diluição do soro foi fundamental para a redução do sinal de fundo e, conseqüentemente, reduzir o número de reações falso-positivas. A utilização de vacinas produzidas em cultivo celular, como por exemplo contra a Febre Aftosa, pode ser uma das prováveis hipóteses que poderiam justificar as inespecificidades encontradas inicialmente, e que foram reduzidas com a inclusão de células MDBK no tampão de diluição do soro. Como o antígeno adsorvido à placa, produzido em cultivo celular, não foi purificado, prováveis anticorpos contra constituintes celulares poderiam ligar-se às proteínas celulares presentes no antígeno gerando reações falso-positivas. A disponibilidade de proteínas celulares no tampão de diluição do soro provavelmente antecipou a ligação dos anticorpos antiproteínas celulares presentes no diluente do soro não disponibilizando-os para aderir-se à placa.

Os valores de sensibilidade, especificidade, preditivo positivo, preditivo negativo e de concordância do ELISA indireto descrito nesse trabalho assemelham-se, ou mesmo são superiores, aos descritos em outros sistemas de ELISA (BOLTON et al., 1981; KRAMPS et al., 1993; HAZARI et al., 2002).

Dos 122 soros avaliados pelo ELISA indireto, apenas quatro apresentaram resultados discordantes da SN. Considerando que os sistemas de ELISA indireto, classicamente, são mais sensíveis que a SN e que dois desses quatro soros apresentaram valor de $\mathrm{R}(0.492$ e 0.572$)$ bem superior ao ponto de corte $(\mathrm{R}=0.409)$ esses resultados podem também ser interpretados como reações falso-negativo na $\mathrm{SN}$. Variações no tempo de incubação vírus/soro (1h ou 24h) podem ocasionar, em alguns soros bovinos, diferenças no título de anticorpos para o BoHV-1 determinados pela técnica de SN (MÉDICI; ALFIERI; ALFIERI, 2000a; HAZARI et al., 2002).

Um soro positivo com título de 4 na $\mathrm{SN}$ apresentou valor de $\mathrm{R}=0.18$ o que o caracteriza como negativo no ELISA indireto. Entretanto, como o sistema foi padronizado para ser utilizado como teste de triagem em amostras de soros provenientes de rebanhos, e não para a definição de infecção ou nãoinfecção de um animal específico, os poucos resultados discordantes encontrados praticamente não 
influenciam, ou interferem muito pouco, em uma avaliação da presença ou da ausência da infecção em rebanhos, bem como da taxa de animais soropositivos.

Para o diagnóstico sorológico da infecção pelo BoHV-1, com freqüência, são utilizadas as técnicas de $\mathrm{SN}$ e kits comerciais de ELISA indireto. A SN, apesar de constituir-se a técnica padrão ouro para a detecção de anticorpos anti-BoHV-1 é uma técnica laboriosa, demorada e que requer a manutenção de linhagens celulares para a sua realização. Adicionalmente, um percentual de amostras pode apresentar resultados inconclusivos devido à presença de soros tóxicos, contaminados e hemolisados. A técnica de ELISA apresenta como vantagem principal a rapidez na conclusão dos resultados e a possibilidade de automação que padroniza os resultados finais. Entretanto, o alto custo é a principal desvantagem dos kits comerciais, nos quais somente o seu valor de aquisição, não considerando os custos necessários para a sua implantação, pode ser superior a US\$ 1.20 por amostra. Esse alto custo pode, em muitas situações, inviabilizar a elaboração de inquéritos soroepidemiológicos.

A disponibilidade de um sistema de ELISA indireto produzido pelo próprio laboratório de diagnóstico e que apresente repetibilidade e altos percentuais de sensibilidade e especificidade, reduz o custo das análises possibilitando a sua utilização tanto como rotina de diagnóstico sorológico quanto em estudos epidemiológicos realizados em grandes amostragens. O sistema de ELISA indireto descrito nesse estudo, além de apresentar bons resultados nos cálculos de validação da técnica, apresenta como vantagens adicionais a facilidade de obtenção de antígeno não purificado e o baixo custo, que possibilitam a sua implantação como técnica para o diagnóstico sorológico da infecção pelo BoHV-1 em rebanhos bovinos.

\section{Agradecimentos}

Os recursos financeiros utilizados para a realização desse trabalho foram obtidos nas seguintes agências de fomento à pesquisa: CNPq, CAPES e Fundação Araucária (FAP/PR).

Alfieri, A. A. é bolsista de produtividade científica do $\mathrm{CNPq}$

\section{Referências}

ACKERMANN, M.; MÜLLER, H. K.; BRUCKNER, L.; KIHM, U. Eradication of infectious bovine rhinotracheitis in Switzerland: review and prospects. Veterinary Microbiology, Amsterdam, v. 23, p. 365-370, 1990.

ALFIERI, A. A.; ALFIERI, A. F.; MÉDICI, K. C. Conseqüências da infecção pelo herpesvírus bovino tipo 1 sobre o sistema reprodutivo de bovinos. Semina: Ciências Agrárias, Londrina, v. 19, n. 1, p. 86-93, 1998.

BIONDI, G. F.; MUCCIOLO, R. G.; NUNES, C. M.; RICHTZENHAIN, L. J. Immunodiagnosis of swine cysticercosis by indirect ELISA employing a heterologous antigen from Taenia crassiceps metacestode. Veterinary Parasitology, Amsterdam, v. 64, p. 261-266, 1996.

BITSCH, V. Persistence of infection with infectious bovine rhinotracheitis virus in Danish cattle herds. Nordisk Veterinaer Medicin, Copenhagen, v. 30, p. 179-185, 1978.

BOLTON, D. C.; CHU, H.; ARDANS, A. A.; KELLY, B.; ZEE, Y.C. Evaluation of the critical parameters of a sensitive ELISA test using purified infectious bovine rhinotracheitis virus antigens. Veterinary Microbiology, Amsterdam, v. 6, n. 4, p. 265-279, 1981.

BRADFORD, M. M. A rapid and sensitive method for the quantitation of microgram quantities of protein utilizing the principle of protein-dye binding. Analytical biochemistry, New York, v. 72, p. 248-254, 1976.

COGGON, T.; ROSE, G.; BARKER, D. J. Measurement, error and bias. In: COGGON, T.; ROSE, G.; BARKER, D. J. (ed) Epidemiology for the Unitiated, 3. ed. London: BMJ Publishing Group, 1983. p. 20-25.

COHEN, J. A. Coefficient of agreement for nominal scale. Educational and Psychological Measurement, Durham, v. 20, p. 37-46, 1960. 
CORTEZ, A.; HEINEMANN, M.B.; ALFIERI,A.A.; MÉDICI, K. C.; ALFIERI, A. F.; OLIVEIRA, D. B.; MEYER, A. D.; RICHTZENHAIN, L. J. Comparação das técnicas de ELISA indireto e de soroneutralização na detecção de anticorpos contra o BHV-1 em amostras de soro de bubalino (bubalus bubalis). Brazilian Journal of Veterinary Research and Animal Science. São Paulo, v. 38, p. 3, p. 146-148, 2001.

FENNER, F. Veterinary Virology. London: Academic, 1987. p. 347-367.

GART, J. J.; BUCK, A. A. Comparison of a screening test and reference test in epidemiologic studies. American Journal of Epidemiology, Baltimore, v. 83, n. 1, p. 593-602, 1966.

GIBBS, E. P. J.; RWEYEMANN, M. M. Bovine herpesviruses. Part I. Bovine herpesvirus 1. Veterinary Bulletin, Farnham Royal, v. 47, n. 5, 1977.

GOULD, E. A.; BUCKLEY, A.; CAMMACK, N.; BARRETT, A. D.; CLEGG, J.C.; ISHAK, R.; VARMA, M. G. Examination of the immunological relationships between flaviviruses using yellow fever virus monoclonal antibodies. Journal of General Virology, London, v. 66, p. 1369-1382, 1985.

HAZARI, S.; PANDA, H. K.; KAR, B. C.; DAS, B. R. Comparative evaluation of indirect and sandwich ELISA for the detection of antibodies to bovine respiratory syncytial virus (BRSV) in dairy cattle. Comparative Immunology, Microbiology \& Infectious Diseases, Oxford, v. 25, p. 59-68, 2002.

KAHRS, R. F. Infectious Bovine Rhinotracheitis: A review and update. Journal of the American Veterinary Medical Association, Schaumburg, v. 171, n. 10, p. 1055-1064, 1977.

KIRKBRIDE, C. A. Manangin and outbreak of liverstock abortion 2: diagnosis and control of bovine abortion. Veterinary Medicine, Lenexa, v. 80, n. 5, p. 70-79, 1985.

KRAMPS, J. A.; QUAK, S.; WEERDMEESTER, K.; van OIRSCHOT, J. T. Comparative study on sixteen enzymelinked immunosorbent assays for the detection of antibodies to bovine herpesvirus 1 in cattle. Veterinary Microbiology, Amsterdam, v. 35, n. 1-2, p. 11-21, 1993.

LANDIS, J. R.; KOCH, G. G. The measurement of observer agreement for categorical data. Biometrics, Washington, v. 33, p. 159, 1977.

MÉDICI, K. C.; ALFIERI, A. A.; ALFIERI, A. F. Avaliação de um ensaio imunoenzimático comercial no diagnóstico sorológico da infecção pelo herpesvírus bovino tipo 1 . Ciência Rural, Santa Maria, v. 30, n. 2, p. 343-346, $2000_{\text {a. }}$
MÉDICI, K. C.; ALFIERI, A. A.; ALFIERI, A. F. Prevalência de anticorpos neutralizantes contra o herpesvírus bovino tipo 1, decorrente de infecção natural, em rebanhos com distúrbios reprodutivos. Ciência Rural, Santa Maria, v. 30, n. 2, p. 347-350, 2000b.

MUELLER, S. B. K.; IKUNO, A. A.; MACHADO, J. S.; LIMA, R. M. A.; RICHTZENHAIN, L. J.; TAKI, E. M. Prevalência de anticorpos contra o vírus da Rinotraqueíte Infecciosa Bovina / Vulvovaginite Pustular Infecciosa (RIB/ VPI) em bovinos do Estado de São Paulo. Instituto Biológico de São Paulo, São Paulo, v. 47, n. 2, p. 55-59, 1981.

OKANO, W.; BRACARENSE, A. P. F. R. L.; REIS, A. C. F. ALFIERI, A. A. Achados histopatológicos em fetos bovinos abortados e não abortados. Arquivo Brasileiro de Medicina Veterinária e Zootecnia, Belo Horizonte, v. 55 , n. 2, p. 223-225, 2003.

PAREDES, J. C. M.; OLIVEIRA, L. G.; BRAGA, A. C.; TREVISOL, I. M.; ROEHE, P. M. Development and standardization of an indirect ELISA for the serological diagnosis of classical swine fever. Pesquisa Veterinária Brasileira, Rio de Janeiro, v. 19, n. 3-4, p. 123-127, 1999.

RAVAZZOLO, A. P.; PIZZOL, M. D.; MOOJEN, V. Evidência da presença de anticorpos para o vírus da Rinotraqueíte Infecciosa dos Bovinos, em alguns municípios do Estado do Rio Grande do Sul, Brasil. Arquivos da Faculdade de Veterinária da Universidade Federal do Rio Grande do Sul, Porto Alegre, v. 17, p. 8995, 1989.

RICHTZENHAIN, L. J.; ALFIERI, A. A.; LEITE, R. C.; WEIBLEN, R.; MORO, E.; UMEHARA, O. Pesquisa de anticorpos séricos contra o herpesvírus bovino tipo $1 \mathrm{em}$ fêmeas bovinas de propriedades com histórico de problemas reprodutivos, localizadas em 21 estados brasileiros. Arquivos do Instituto Biológico, São Paulo, v. 66, supl., p. 127, 1999.

ROIZMAN, B.; DESROSIERS, R. C.; FLECKENSTEIN, B.; LOPES, C.; MISSON, A. C.; STUDDERT, M. J. The family Herpesviridae: an update. Archives of Virology, New York, v. 123, p. 425-449, 1992.

STRAUB, O. C. BHV-1 Infectious: Relevance and spread in Europe. Compendium in Immunology, Microbiology and Infectious Diseases, Oxford, v. 14, n. 2, p. 175-186, 1991.

TAKIUCHI, E.; ALFIERI, A. F.; ALFIERI; A. A. Herpesvírus bovino tipo 1: Tópicos sobre a infecção e métodos de diagnóstico. Semina: Ciências Agrárias, Londrina, v. 22, n. 2, p. 203-209, 2001. 
TAKIUCHI, E.; MÉDICI, K. C.; ALFIERI, A. F.; ALFIERI, A. A. Otimização da reação em cadeia pela polimerase (Semi Nested-PCR) para a detecção do herpesvírus bovino tipo 1 em fragmentos de órgãos fetais e em sêmen de bovinos naturalmente infectados. Semina: Ciências Agrárias, Londrina, v. 24, n. 1, p. 43-56, 2003.

TAKIUCHI, E.; MÉDICI, K. C.; ALFIERI, A. F.; ALFIERI, A. A. Bovine herpesvirus type 1 abortions detected by a semi nested-PCR in Brazilian cattle herds. Research in Veterinary Science, London, v. 78, n. 4, 2005. No prelo.
VIDOR, T.; HALFEN, D. C.; LEITE, T. E.; COSWIG, L. T. Herpes bovino tipo 1 (HVB-1): I. Sorologia de rebanhos com problemas reprodutivos. Ciência Rural, Santa Maria, v. 25, n. 3, p. 421-424, 1995.

WYLER, R.; ENGELS, M.; SCHWYZR, M. Infectious bovine rhinotracheitis / vulvovaginitis (HVB-1). In: WITTMANN, G. (ed.) Herpesvirus diseases of cattle, horses and pigs. Boston: Kluwer Academic Publishers, 1989. p. 1-72. 